\title{
造船における半自動溶接の現状*
}

\author{
有川正康**
}

\section{Status of Semi-Automatic Welding in Shipbuilding*}

by Masayasu Arikawa**

\section{1.まえがき}

日本の造船界はサブマージアーク溶接法による自動溶 接之高酸化鉄系の太径溶接棒倸上る水平すみ肉溶接の 2 つを主体として地上工程の合理化, 能率化を計り, ブロ ック建造法の確立を成功させたととは周知のとおりであ るが，さらに造船工程全般にわたる溶接の自動化, 専用 化が皘極的に進められ，地上の板継工程における片面自 動溶接の奏用化をはじめ，ロンデ材と主板の取合部の水 平すみ肉のサブマージアーク溶接法, 船台上での側外板 のエレクトロスラグ溶接法や，内構部材を対象とした消 耗ノズル式エレクトロララグ溶接法などが炊々に採用さ れ，実用化されている。

いっぽう半自動溶接は，既に10数年前に $\mathrm{CO}_{2}$ ガス アーク溶接法が紹介され，他業種において積極的に導入 されていったのに対して，造船での本格的な採用はなさ れないまま過ぎてきたが，ノンガスアーク溶接法の出現 した和和 40 年頃より，ノンガスアーク溶接の導入実験と ともに $\mathrm{CO}_{2}$ ガスアーク溶接法の再検討がはじめられ， その後これらの溶接材料の使用量あ徐々にではあるが增 加しつつある.またさらに，従来半自動溶接として用い られているてれらの溶接法をべースに新しい省力化機器 と組合せた自動溶接法としての発展もめざましいものが あり，造船に扔ける半自動溶接の今後は，連続的飞送給 されてくる溶接ワイヤによにアークを発生せしめ，作業 者が溶接線に沿ってアークを移動させるという従来の概 念を超えた形態で拡大していくととが予想される.

本文では造船所における半自動溶接法の適用状沉を紹 介するととむに，その将来について述べることにした い.

\section{2. 造船における半自動溶接の位置}

半自動溶接法は他の溶接法之比較して

(1) 手溶接の1.5倍〜 3 倍の能率である.

（2）各種自動溶接法に較べて機器が安価で, 操作む

*原稍受付 昭和 47 年 6 月 8 日

**正員 神戸製鍓所 (株) Member, Kobe Steel L.td.
簡単である。

（3）継手の種類, 姿勢を問わず適用可能である.

などの特長があり, サブマージアーク溶接の適用可能 な継手のほとんどの箸囲が自動化されている考えられる 現状では，さらに高能率化，自動化の拡大をはかるに は，半自動溶接の採用および適用個所の拡大が有効であ り，また近道でああるととは言うまですないが，図1亿 示すごとく全国主要造船所の溶材接料の使用比率のうち で半自動溶接材料の占める割合は昭和 46 年度で約 $0.9 \%$ 程度と極めて少ない現状にある.乙の数字は昨年 1 年間

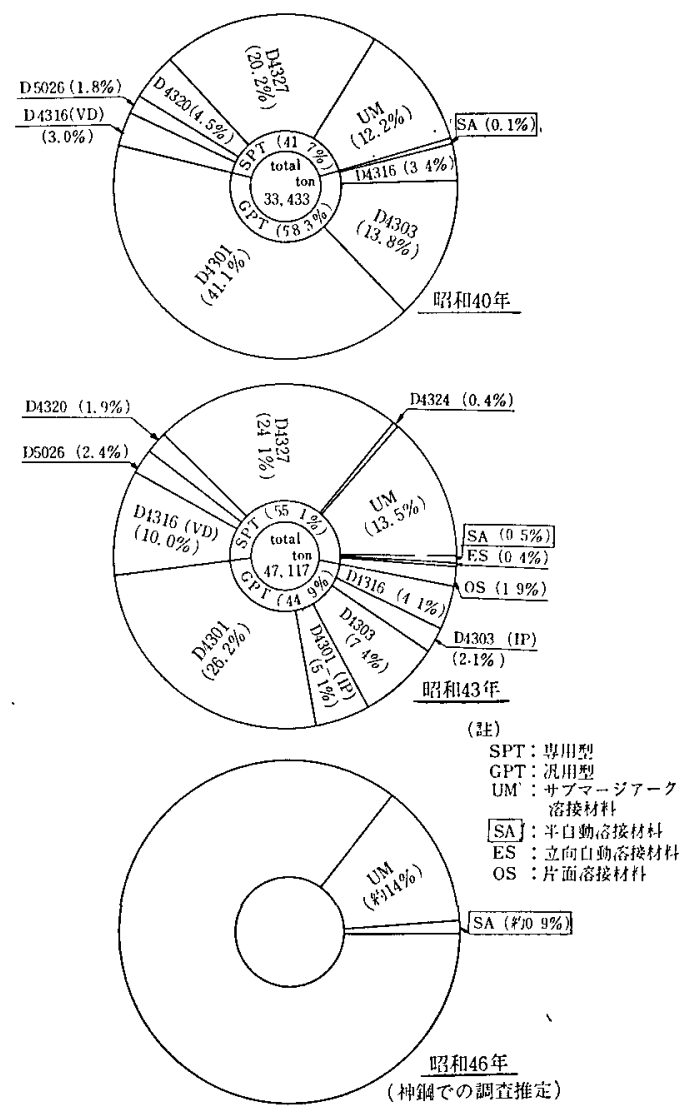

図 1 全国主装造船所溶接材料使用比率 （昭和 $40 ， 43$ 年溶接揓工委謂べ） 
表1 全国溶接材料生産量*1 （昭和46年 1 月～12月累計，溶接協会調べ）

\begin{tabular}{|c|c|c|c|c|}
\hline & 稙 & 類 & 生产量 ( $\mathrm{T} /$ 年) & 此棸 (\%) \\
\hline & 被 & 澓 & 336,880 & 85,7 \\
\hline & $\pi$ & x & 2,261 & 0,6 \\
\hline サブマー & - & ソリッド & 18,779 & 4,7 \\
\hline & & チューブラー & 444 & 0,1 \\
\hline ガスシー & ールト & ，ソリット & 30,119 & $7,7) 8.8$ \\
\hline & & チューブラー*2 & 4,204 & $1,1\}^{8,8}$ \\
\hline . & そ & の 他 & 123 & \\
\hline & 合 & 計 & 392,810 & - \\
\hline
\end{tabular}

の全国溶接材料の生産量之その棈成比率を示す, 表 $1 の$ 半自動溶接材料の比率約 $8.8 \%$ と対照すれば，現状では 造船においてまだ半自動溶接は大きなウェイトをもって いないととを客観的场語っている。

しかし，図 1 の半自動材料の使用比率は昭和 40 年の $0.1 \%$ 亿対して，昭和 43 年度は $0.5 \%$, 昭和 46 年度は約 0.9\% 之着実に増加して扰り，サブマージアーク溶接材 料の使用比率がほほ横ばいであるのに対して，その伸び 率は大きい，之語えよう。また図 2 は全国主要造船所に おける半自動溶接機の所有台数と半自動ワイヤ使用量の 過去 7 年間の推移を示すものであるが，最近半自動溶接 の桩大がかなり皘極的に推進されているととがうかがわ れる。

\section{3. 造船における半自動溶接の適用}

2.で述べたでとく，現在まだ全般的に普及している 之は言い難い半自動溶接も，いくつかの造船所飞おいて は，意欲的任採用されており，その適用個所も多種にわ たっている。

これら半自動溶接を積極的に採用している造船所で は，管理者あるいは計画推進者の半自動溶接に対する認 識と評価が充分であり，その方向づけが適切で，かつそ の実施計画之手段が作業者受け入れられていることが 特長であるが，さらに後に述べる半自動溶接の有する造 船現場への実用化の困難を改善しようとする長年にわた る担当技術者や現埸指導者の努力がはらわれているとと を認める必要がある.

\section{1 適用個所}

半自動溶接の適用されている主な溶接姿勢は，水平す み肉（下向すみ肉，傾斜のあるすみ肉を食む）之下向ま たは傾斜のある突合せおよび横向突合であり，立向，上 向姿勢への適用はごく一部に限られている.これは半自 動溶接が立向, 上向などいわゆる全姿勢溶接が可能であ るとしても，現状ではこれらの姿では溶接電流が手溶接 と変らず, 能率の向上が期待できないととと, 半自動溶
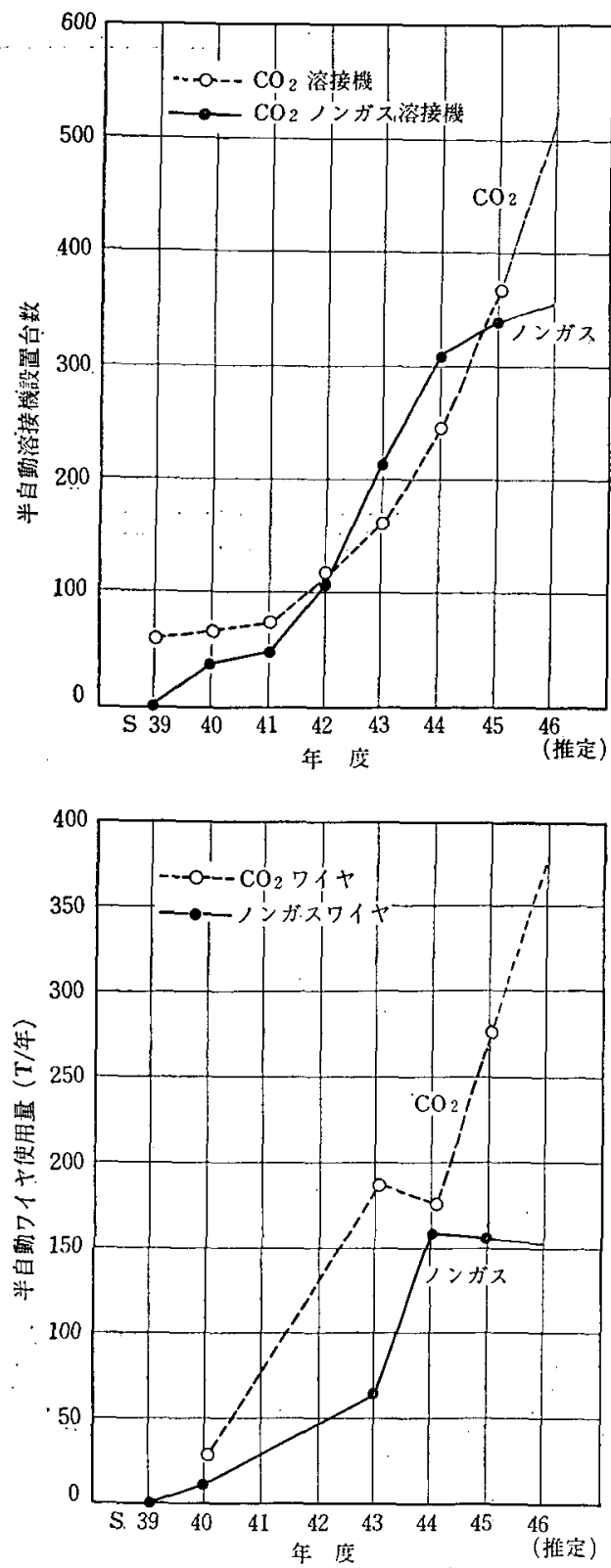

図 2 全国主要造船所の半自動溶接機設罟台数 とワイヤ使用量の変化(溶接施工委調べ)

接を採用することによって作業者に要求する技量の熟練 度が低くてよいとは言えないととによる。

さらに水平すみ肉に関しても，グラビティや低角度方 式以上の経済性の能率性は望むべくもなく，たとえグラ ビティ方式によらなくても，鉄粉酸化鉄系（D4327）の 溶接棒はコンタクト型で作業が容易であり，ビード外 観, 形状の点でも半自動溶接の優位性は己しく，また立 向すみ肉においてもコンタクト型の下淮棒が普及してお り, 平均して船体溶接長の約 $80 \%$ をす肉でらめるとと 


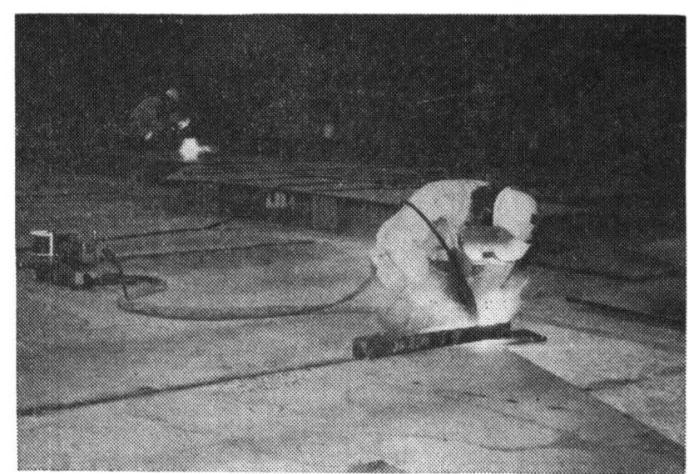

写真 1 小組工程における薄板の板継 $\left(\mathrm{CO}_{2}\right.$ ガスアーク溶接 $)$

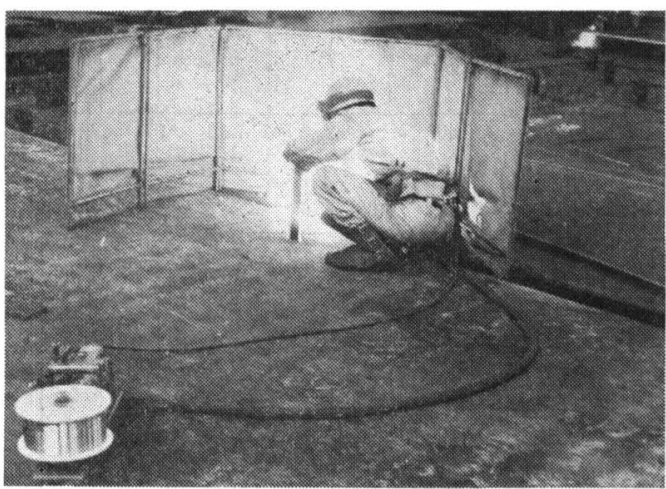

写真 2 吊上ピースの取付状況 $\left(\mathrm{CO}_{2}\right.$ ガス・アーク溶接 $)$

をも考え合せれば, 半自動溶接の適用範囲はかなり限定 されてくることになる.

\section{(1) 内業工程}

風の影響を受けやすい造船所においては屋内工程では 半自動溶接の有利な環境にあり, サプマージアーク溶接 の適用による効果の小さい薄板, 短尺の板継, 吊上反転 用ピース, 補機台などの大脚長すみ肉, サブマージ片面 溶接のタブ板の 取付など主として $\mathrm{CO}_{2}$ ガスアーク溶接 が用いられている。

\section{(2) 組立工程}

内業に扔いては半自動溶接は継手長の短かいものを主 体に, サブマージアーク溶接の準備作業之移動運般の不 便さをカバーするため補助手段として用いられている感 がするが，組立工程においては内業と同じく薄板の板継 や各種すみ肉とともに, 外板または船首, 船尾の曲り之 勾配のある継手に採用されている。乙れらの継手のうち $10^{\circ}-10^{\circ}$ までの比較的傾斜の緩やかなあのはサブマージ アーク溶接材料の進歩により自動溶接が可能となった が, それ以上の曲り之傾斜の急な船首, 船尾ブロックの 継手は半自動溶接が必要となってくる．ととに高速貨物
船などにおいては平行部に較べて曲り部の占める割合が 大きく，半自動溶接の採用によるアーク時間の節減効果 は大きい，その他, 上部構造, 舵, スタンフレーム,な ぞも半自動溶接の対象となる。

\section{(3) 船台工程}

風の影響をむっとも受けやすい工程であるが，場所に よっては，周囲が外板類，内構部材などに囲まれた状態

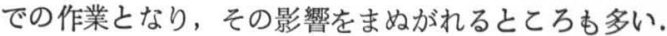

船底外板のシーム捄よびバット，デッキプレートのシ 一ムおよびバットのうち，船底外板のバットは $1 \mathrm{~m}$ 前 後の間隔で並ぶロンヂ材が配されているため, $\mathrm{CO}_{2}$ ガ ス・半自動溶接が用いられ, 船底のシームはサブマージ アーク溶接が多い、デッキプレートもサブマージアーク 溶接が可能であるが, 開先精度が地上工程より悪く, $\mathrm{CO}_{2}$ ガス半自動溶接とサブマージアーク溶接の併用さ れることが多い。

側外板の横シームには $\mathrm{CO}_{2}$ ガス自動溶接またはノン ガスの自動容接を行なっている造船所が数力所づつあ る.

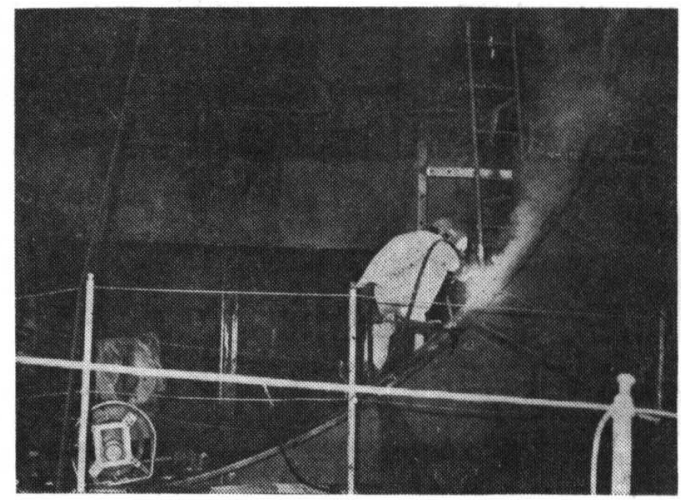

写真 3 船台工程におけるボトムトランスのフェー スプレートの突合（ノンガスアーク溶接）

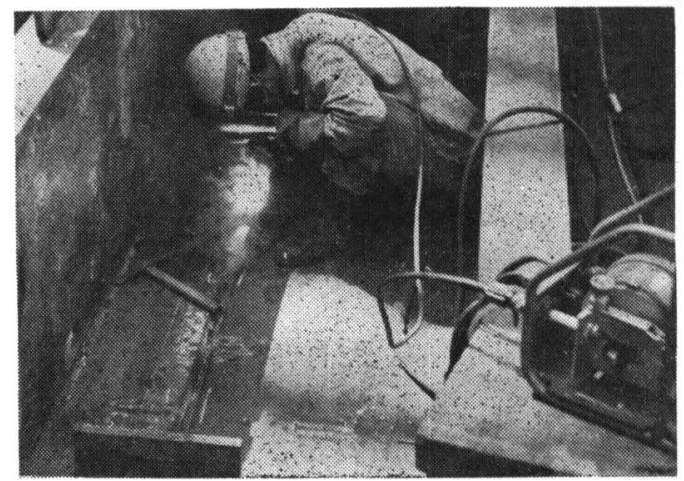

写真 4 船台工程に打ける船底外板のブロック継手 の片面溶接（シーム方向， $\mathrm{CO}_{2}$ ガスアーク 溶接) 
表 2 Cargo Liner, Bulk Carrier の半自動溶接の適用個所 ${ }^{1)}$

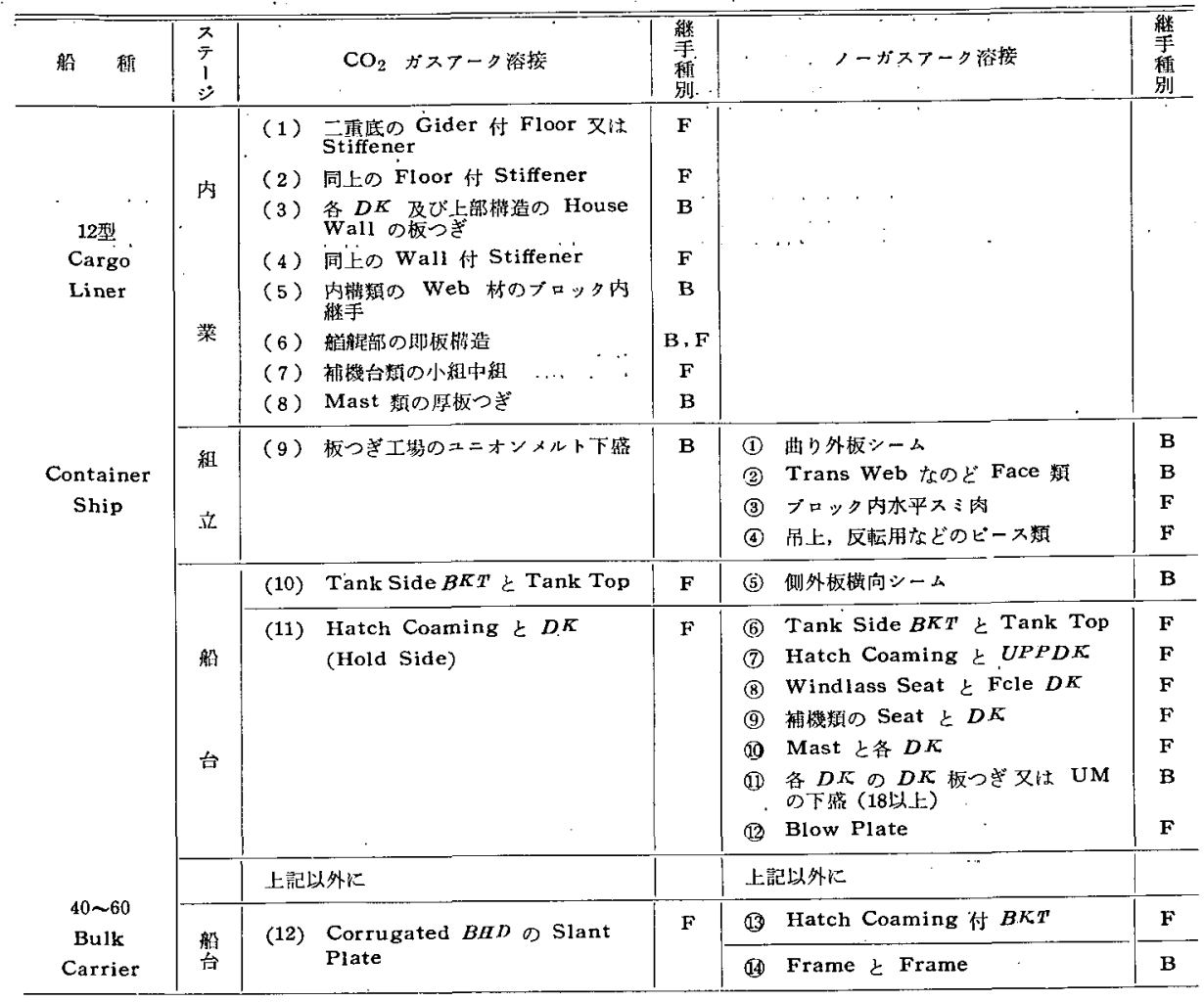

F : ナみ肉 B：突合せ
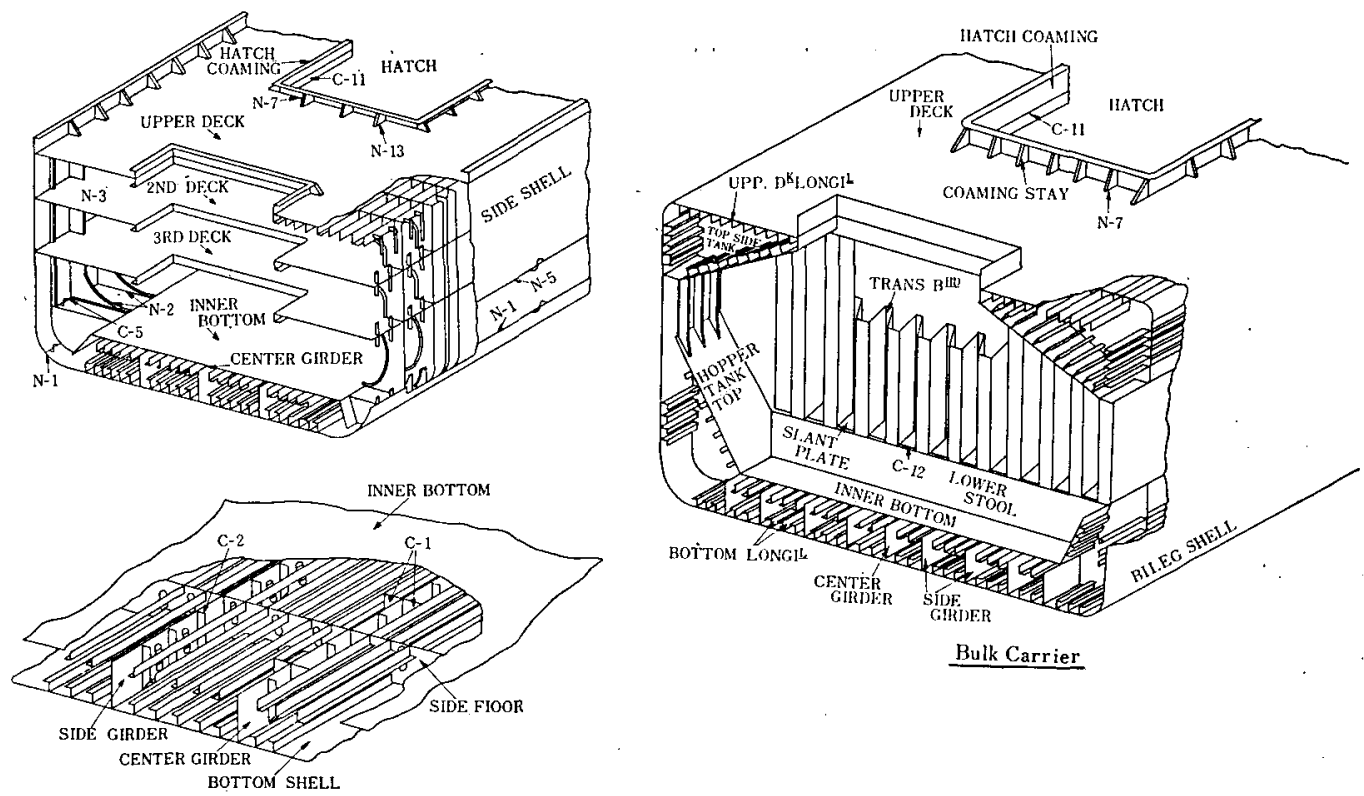

Bulk Carrier

- Cargo Liner.

図 3 Cargo Liner, Bulk Carrier の断面俯瞰図 
また板厚の大きいトランスリングのフェースプレート 類にはノンガスアーク溶接がよく使用されており，鉱石 船の二重底とタンクトップのすみ肉や，ホッパータンク トップの横シームもノンガス半自動溶接が用いられ る.

表 2，3，図 3，4 亿各船型の半自動溶接の適用 個所 例を示しているが，全般的にみると，屋内作業を主とす
る内業, 組立工程には $\mathrm{CO}_{2}$ ガスアーク溶接が, 船台工 程では $\mathrm{CO}_{2}$ ガスアーク溶接とノンガスアーク溶接が使 用されている.

実船への半自動溶接の適用による能率向上の ゙゙ータ はあまり発表されていないが表 4 にその一例を示す．表 4 のデータによれば, 大脚長のすみ肉と板厚の大きい突 合せ継手で大ゆな作業時間の短縮が可能であることが実

表 3 Tanker の半自動溶接適用個所例

\begin{tabular}{|c|c|c|}
\hline $\begin{array}{l}\pi \\
\bar{\nabla} \\
1 \\
\vdots\end{array}$ & $\mathrm{CO} 2$ ガスフーク溶接 & ノンガスフーク溶接 \\
\hline 内 & 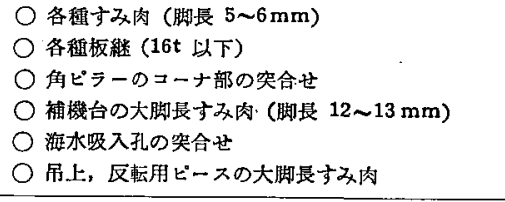 & · \\
\hline 租 & 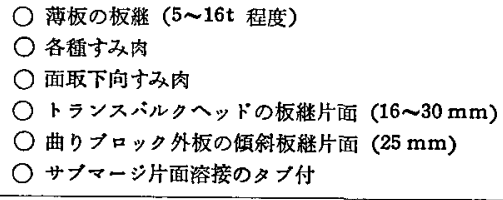 & \\
\hline 台 & 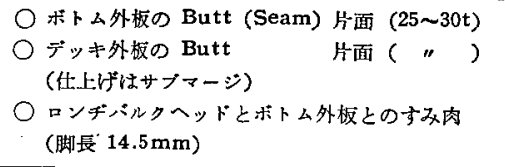 & 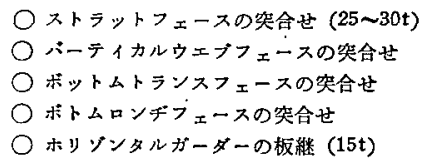 \\
\hline
\end{tabular}

表 4 半自動溶接と手溶接の実船での能率比較例2)

\begin{tabular}{|c|c|c|c|c|c|c|c|c|c|}
\hline \multirow{2}{*}{ 湲 } & \multirow[b]{2}{*}{ 適 用 桠 造 } & \multirow{2}{*}{$\begin{array}{c}\text { 実测 } \\
\text { 溶接長 } \\
\text { (m) }\end{array}$} & \multicolumn{2}{|c|}{ 溶接 時閒 } & \multicolumn{2}{|c|}{ 能率 } & \multirow[b]{2}{*}{$\begin{array}{l}\text { 能率化 } \\
\text { (A)/B) }\end{array}$} & \multirow[b]{2}{*}{ 備 } & \\
\hline & & & $\begin{array}{c}\text { 半自動 } \\
\text { 溶 接 } \\
(\mathbf{h r})\end{array}$ & $\begin{array}{c}\text { 手溶接 } \\
(\mathrm{hr})\end{array}$ & $\begin{array}{c}\text { 半自動 } \\
\text { 溶 } \\
(\mathrm{m} / \mathrm{hr}) \text { (A) }\end{array}$ & $\begin{array}{c}\text { 手溶接 } \\
(\mathrm{m} / \mathbf{h r}) \text { (B) }\end{array}$ & & & \\
\hline \multirow{6}{*}{ 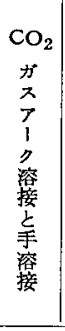 } & $\stackrel{\text { UPDK }}{\text { BUTT }}$ & 396 & 609 & 857 & 0.65 & 0.46 & 1.4 & $\begin{array}{c}\text { 下向实合せ } \\
\mathrm{t}=30 \mathrm{~mm}\end{array}$ ワイヤ径 $1.6 \mathrm{~mm} \phi$ & （船台） \\
\hline & 大組ブロック吊上ビス & 0.58 & 0.17 & 0.63 & 3.4 & 0.9 & 4.0 & $\begin{array}{l}\text { 水平すみ肉 } \\
\text { 脚長 } 20 \mathrm{~mm}\end{array}$ & (組立 $)$ \\
\hline & F, C, B, 終端処理 & 1.6 & 0.75 & 3.0 & 2.1 & 0.53 & 4.0 & $\begin{array}{c}\text { 下向突合せ } \\
\mathbf{t}=30 \mathrm{~mm}\end{array} \quad$ ワイ径 $1.6 \mathrm{~mm} \phi$ & （内業） \\
\hline & 階 C 段 & 16.3 & 2.5 & 4.0 & 6.5 & 4.1 & 1.6 & $\begin{array}{l}\text { 水平すみ肉就よび立向すみ肉下進 } \\
\text { ワイヤ径 } 1.2 \mathrm{~mm} \text { 脚長 } 4 \mathrm{~mm}\end{array}$ & （内業） \\
\hline & $\begin{array}{c}\mathbf{B} \\
\text { 小組部材全般 }\end{array}$ & 65.1 & 7.0 & 10.5 & 9.4 & 6.3 & 1.5 & $\begin{array}{l}\text { 水平すみ肉 ワイヤ径 } 1.6 \mathrm{~mm} \phi \\
\text { 眑艮 } 6 \mathrm{~mm} \text { (ク゚ラビテの残り) }\end{array}$ & （内業） \\
\hline & HATCH, COAM $\stackrel{\text { 船 }}{\mathrm{C}}$ MING & 252 & 325 & 585 & 0.78 & 0.43 & 1.8 & $\begin{array}{l}\text { 氷平レ形 ワイヤ径 } 1.6 \mathrm{~mm} \phi \\
\mathbf{t}=12\end{array}$ & (船台) \\
\hline \multirow{6}{*}{ 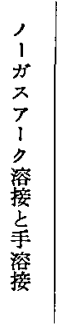 } & $\mathrm{V}, \underset{\mathrm{WEB}}{\mathrm{T}}$ の $\mathrm{FACE}_{\mathrm{A}}$ & 93 & 345 & 547 & 0.27 & 0.17 & 1.6 & $\begin{array}{l}\text { 横向突合せ ワイヤ径 } 3.2 \mathrm{~mm} \phi \\
\mathrm{t}=32 \mathrm{~mm} \phi \text { (1個所の WL } 0.58 \mathrm{~m})\end{array}$ & （船台） \\
\hline & C, GIRDER $\stackrel{\text { 船 }}{の} \mathrm{FACE}$ & 43 & 78 & 165 & 0.55 & 0.26 & 2.1 & $\begin{array}{l}\text { 下向突合せ ワイヤ彽 } 3.2 \mathrm{~mm} \phi \\
\mathrm{a}=35 \mathrm{~mm} \text { (1個所の WL } 1.6 \mathrm{~m} \text { ) }\end{array}$ & （船台） \\
\hline & 䑪内， PILLAR & 1.15 & 3.0 & 7.0 & 0.38 & 0.16 & 2.4 & $\begin{array}{l}\text { 水平レ形 } \\
\mathrm{t}=16 \mathrm{~mm}\end{array}$ & （船台） \\
\hline & 㑡 外 板 船 & 570 & 531 & 779 & 1.07 & 0.73 & 1.5 & $\begin{array}{l}\text { 满向突合せ ワイヤ径 } 3.2 \mathrm{~mm} \phi \\
\mathrm{t}=13 \sim 16 \mathrm{~mm}\end{array}$ & （船台） \\
\hline & ENGINE SEAT & 1.1 & 5.0 & 9.0 & 0.22 & 0.12 & 1.8 & 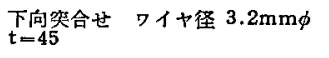 & （沿台） \\
\hline & HATCH COAMING & 368 & 113 & 132 & 3.25 & 2.79 & 1.2 & 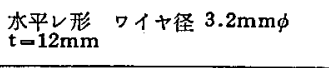 & （船台） \\
\hline
\end{tabular}

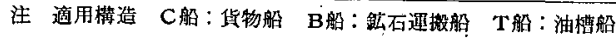




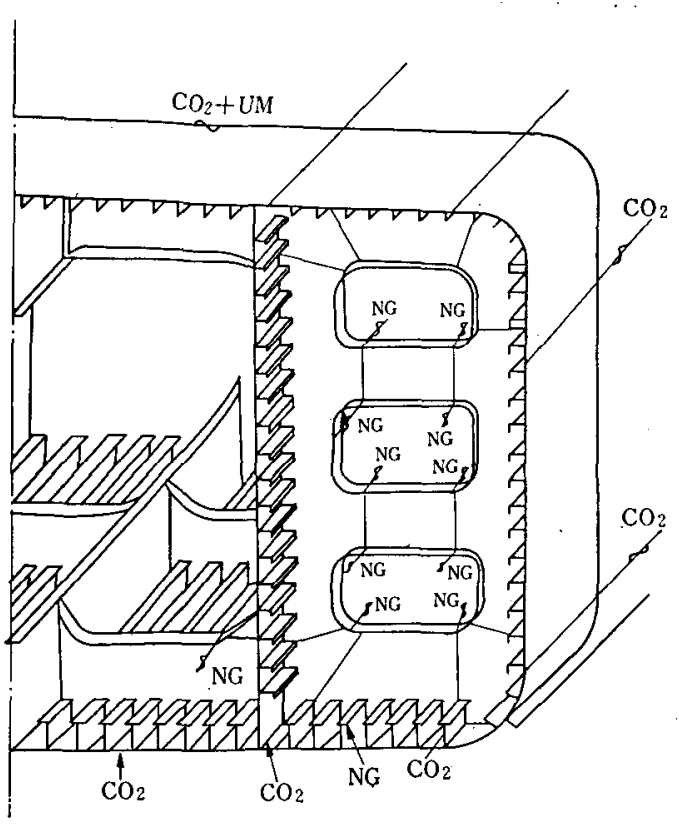

図4 Tanker の断面侮瞰図

証されている.

\section{2 片面溶接}

船台工程での突合せ継手を半自動溶接で行なう場合， かなりの部分が片面溶接で行なわれており，半自動溶接 のメリットを大きくしている．船台でのブロック間の咨 合せは反転作業が不可能であり，下向溶接といえどもか ならず上向姿攀のガウジング作業と溶接作業が不可避で あったが，片面溶接化による工数節減と作業環境の改普 効果は著しいすのがある。（表 5 ，表 6 ）
船台でのプロック同志の接合は地上の板継に較べて開 先精度が恵く，可視アークで作業者が溶接部を観察しな がら必要に応じて溶接条件や運棒操作をコントロールす ることが可能で, かつ傾斜, 曲面部での適用できる半自 動溶接は，サブマージアーク溶接に較べてきわめて有利 である.さらに片面溶接化する場合，手溶接では溶接棒 1 本ごとのビードの継が避けられず, 継目部の品質の不 安定さを内蔵している。

以上の理由から造船における半自動溶接適用掋大の少 なからぬ部分は片面溶接化とともに進んできており，今．

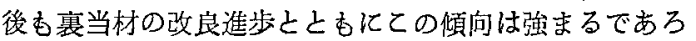
う. 裹当材の種類は数多いが, 耐火層とスラグ生成層の 2 唐からなる固形フラックスをメタルケースで包んだタ イプ（カタフラックス）のあの之最近開発された特殊ガ ラステープと耐熱テープにより構成された可捥性を有す るロール状の㜊当材（F R B）の 2 つが主に用いられて いる.

ワイヤについては $\mathrm{CO}_{2}$ ガスアーク溶接の場合，片面 溶接部初層のわれの発生防止之衝䈠值の確保のための細 径フラックススりワイヤが主とし用いられており，継手 の性能む各般級の規格を満足させるすので, 重要部（バ ット）への適用も可能ならしめている.表 7 亿各種亭当 材およびワイヤによる片面溶接部の継手性能を, 表 8 亿 日本海事坫会の継手の衝撃值の規定のうちの軟鋼の規格 值を示している. 自動溶接と手溶接では異なる格規值が 設けられているが，NVを除く他の船級では，半自動溶 接賃業者の技量その他の因子からの影響を受けやすい として手溶接に準ずる規定となっている。

\section{3 . 3 造船における半自動溶接の問題点}

表 5 炭酸ガス半自動片面溶接条件例（ワイヤ DWS-52 1.2申）(裹当材 FRB-3）

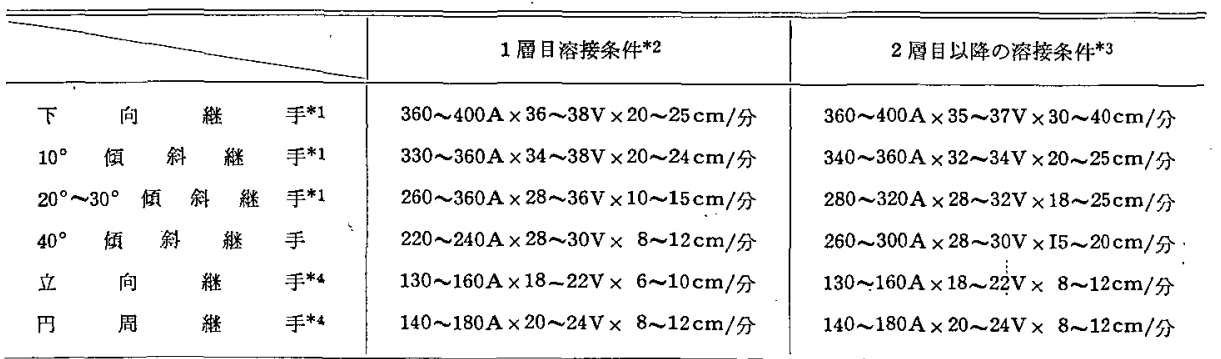

*1:メタルパウダー敬布量 (Gap $2 \mathrm{~mm}: 2 \mathrm{~mm}$, Gaq $4 \mathrm{~mm}: 4 \mathrm{~mm}$, Gap $6 \mathrm{~mm}: 6 \mathrm{~mm}$ )

*2:ワイヤ倾斜度度

*3：ワイヤ傾斜角度

${ }_{4} 4:$ ショートフーク溶捖
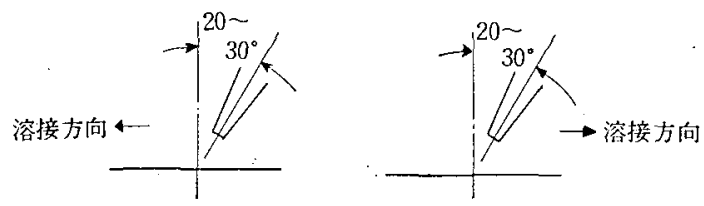
表 6 炭酸ガス半自動片面溶接による溶接時間の短縮 板厚 $19 \mathrm{~mm} 50^{\circ} \mathrm{V}$ 開先の $9 \mathrm{~m}$ 当りの嚓接特間比较例

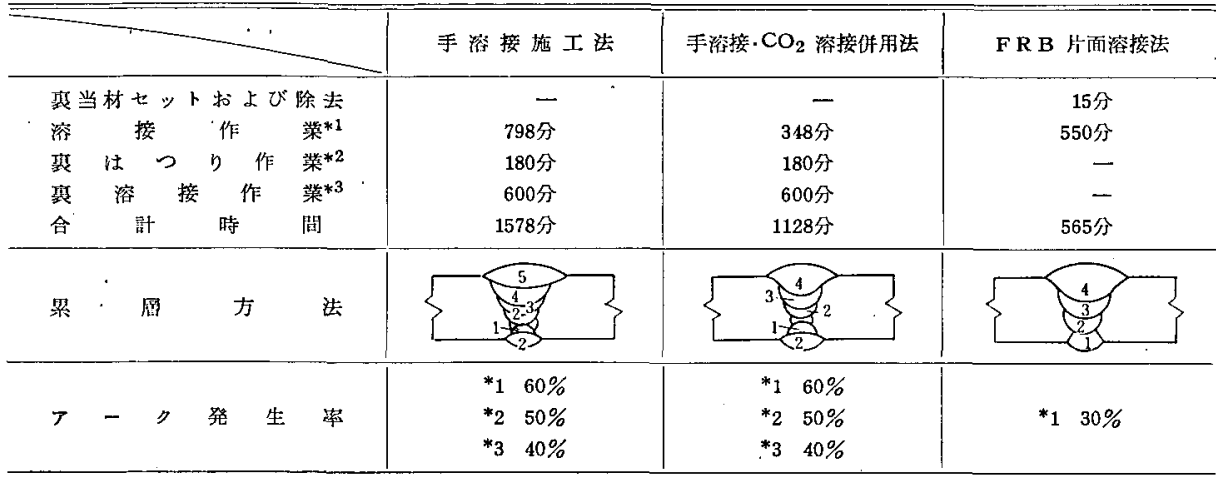

表 7 半自動片面溶接部の機械的性能

DWS $-52(1.6 \mathrm{~mm}) \times$ FRB-3 に上る片面浴接部の機械的性能（一例）

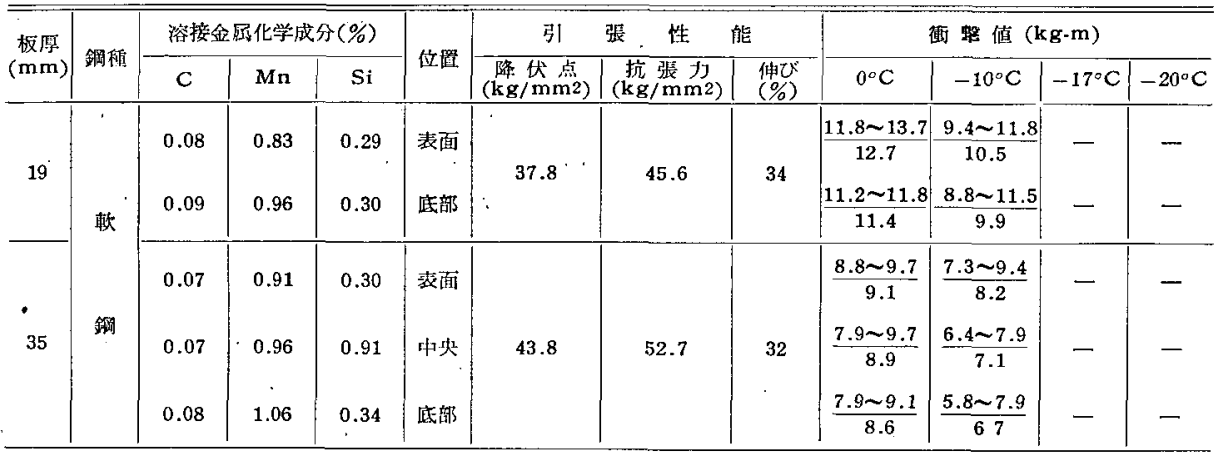

DWS-52kよる歌鍼カタフラックス $\mathrm{CO}_{2}$ 片面溶接部の生能

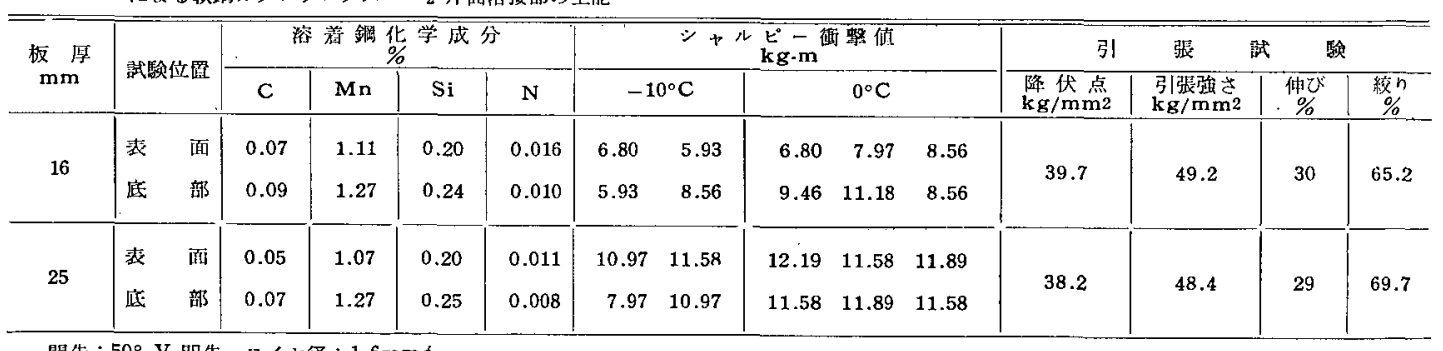

開先: $50^{\circ}-\mathrm{V}$ 閒先, ワイヤ登: $1.6 \mathrm{~mm} \phi$

$\mathrm{BB}$ 法片面溶接部の性能

\begin{tabular}{|c|c|c|c|c|c|c|c|c|c|c|c|c|c|c|c|}
\hline \multirow{2}{*}{ 溶 } & \multirow{2}{*}{$\begin{array}{c}\text { 板 } \\
\mathrm{mm}\end{array}$} & \multirow{2}{*}{ 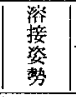 } & \multicolumn{2}{|c|}{ 溶 搂 材 料 } & \multirow{2}{*}{$\begin{array}{l}\text { 試 } \\
\text { 魜 } \\
\text { 俭 } \\
\text { 䍡 }\end{array}$} & \multicolumn{3}{|c|}{ 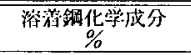 } & \multirow{2}{*}{\multicolumn{3}{|c|}{ 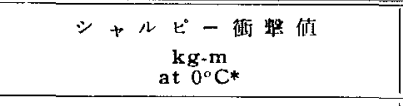 }} & \multirow{2}{*}{$\begin{array}{l}\text { 引张強 } \mathrm{x} \\
\mathrm{kg} / \mathrm{m} \mathrm{m} 2\end{array}$} & \multirow{2}{*}{$\begin{array}{c}\text { 伸び } \\
\%\end{array}$} & \multicolumn{2}{|c|}{ 北げ性能 } \\
\hline & & & 浴接棒 & 褧当材 & & C & $\mathbf{M n}$ & $\mathbf{S i}$ & & & & & & $\bar{x}$ & 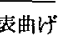 \\
\hline \multirow{2}{*}{$\begin{array}{l}\text { 溶 } \\
i \\
\text { 方接 }\end{array}$} & 16 & 立向き & $\begin{array}{c}\text { OW }-56 \\
2.4 \phi\end{array}$ & BB-2 & & & & & 4.80 & 5.08 & $4.80 \quad(4.89)$ & \multirow[b]{2}{*}{48.8} & \multirow[b]{2}{*}{ 舟秋破断 } & \multirow[b]{2}{*}{ 主好 } & \multirow[b]{2}{*}{ 县好 } \\
\hline & 32 & 下何导 & $\begin{array}{c}\mathrm{OW}-56 \\
3.2 \phi\end{array}$ & " & $\begin{array}{l}\text { 底部 } \\
\text { 表酒 }\end{array}$ & 0.08 & 0.98 & 0.10 & $\begin{array}{r}4.53 \\
10.67\end{array}$ & $\begin{array}{r}4.53 \\
10.98\end{array}$ & $\begin{array}{cccc}5.08 & 2.68 & 3.99 & (4.16) \\
9.15 & 9.15 & 11.28 & (10.25)\end{array}$ & & & & \\
\hline \multirow{2}{*}{$\begin{array}{l}\text { 炭 } \\
\text { 酸 } \\
\text { 方 } \\
\text { 不 } \\
\text { 溶 } \\
\text { 淁 }\end{array}$} & $\begin{array}{l}\text { 䫒 } \\
\text { 錭 } \\
25\end{array}$ & 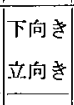 & $\begin{array}{c}\mathrm{MG}-50 \mathrm{~T} \\
1.2 \phi \\
\prime \prime\end{array}$ & $\mathrm{BB}-3$ & $\begin{array}{c}\text { 底部 } \\
\end{array}$ & $\begin{array}{l}0.10 \\
0.10\end{array}$ & $\begin{array}{l}1.21 \\
1.01\end{array}$ & $\begin{array}{l}0.61 \\
0.53\end{array}$ & $\begin{array}{l}7.37 \\
7.37\end{array}$ & $\begin{array}{l}7.97 \\
8.26\end{array}$ & $\begin{array}{lll}8.55 & 8.26 & (8.03) \\
7.67 & 8.55 & (7.96)\end{array}$ & $\begin{array}{l}50.6 \\
51.1 \\
50.1 \\
49.4 \\
\end{array}$ & $\begin{array}{c}\text { 母材破断 } \\
" \\
" \\
"\end{array}$ & $"$ & $"$ \\
\hline & 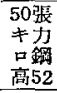 & 下向き & $"$ & $"$ & $"$ & $\begin{array}{l}0.11 \\
0.10\end{array}$ & 1.12 & $\begin{array}{l}0.61 \\
0.53\end{array}$ & $\begin{array}{l}7.97 \\
7.08\end{array}$ & $\begin{array}{l}5.92 \\
5.92\end{array}$ & $\begin{array}{lll}5.92 & 5.64 & (6.36) \\
9.44 & 9.44 & (7.95)\end{array}$ & $\begin{array}{l}58.8 \\
60.0 \\
56.8 \\
57.6\end{array}$ & $\begin{array}{l}\prime \prime \\
" \prime \\
\prime \prime\end{array}$ & $"$ & $"$ \\
\hline
\end{tabular}

* 50 キロ高張力鎆の垛合のみ $-10^{\circ} \complement$ 
表 8 ・鋼船規則による衝撃值の規格值（日本海事協会）

\begin{tabular}{|c|c|c|c|c|c|}
\hline 銅 材 & 䋘手の嘎知 & 誐䍄温度 & 手溶 接 & 自醉溶接 & 試簽甹採取位圆 \\
\hline \multirow[t]{2}{*}{ 曈 } & KE 钢の枮縁継手 & $-10^{\circ} \mathrm{C}$ & $\begin{array}{c}6.2 \mathrm{~kg} \cdot \mathrm{m} \\
\text { 以上 }\end{array}$ & $\begin{array}{c}4.5 \mathrm{~kg}-\mathrm{mi} \\
\text { 以上 }\end{array}$ & \multirow{3}{*}{ 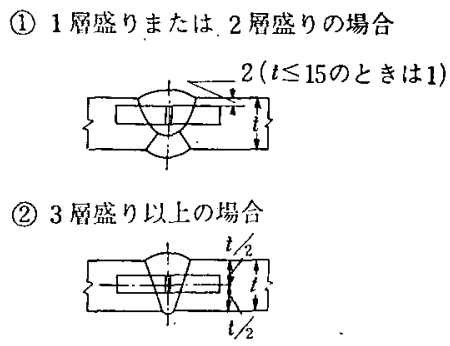 } \\
\hline & $\begin{array}{l}\mathrm{KB}, \mathrm{KC}, \mathrm{KD} \text { 銅 } \\
\text { の椛緑継手 }\end{array}$ & $0^{\circ} \mathrm{C}$ & $\begin{array}{c}4.8 \mathrm{~kg}-\mathrm{m} \\
\text { 以上 }\end{array}$ & $\begin{array}{c}3.5 \mathrm{~kg}-\mathrm{m} \\
\text { 以上 }\end{array}$ & \\
\hline 鍕 & $\begin{array}{l}\text { 上記以外の軟銅の } \\
\text { 継梨 }\end{array}$ & $20^{\circ} \mathrm{C}$ & $\begin{array}{c}4.8 \mathrm{~kg}-\mathrm{m} \\
\text { 以上 }\end{array}$ & $\begin{array}{c}3.5 \mathrm{~kg}-\mathrm{m} \\
\text { 以上 }\end{array}$ & \\
\hline
\end{tabular}

表 9 造船所における半自動溶接の主要問題点

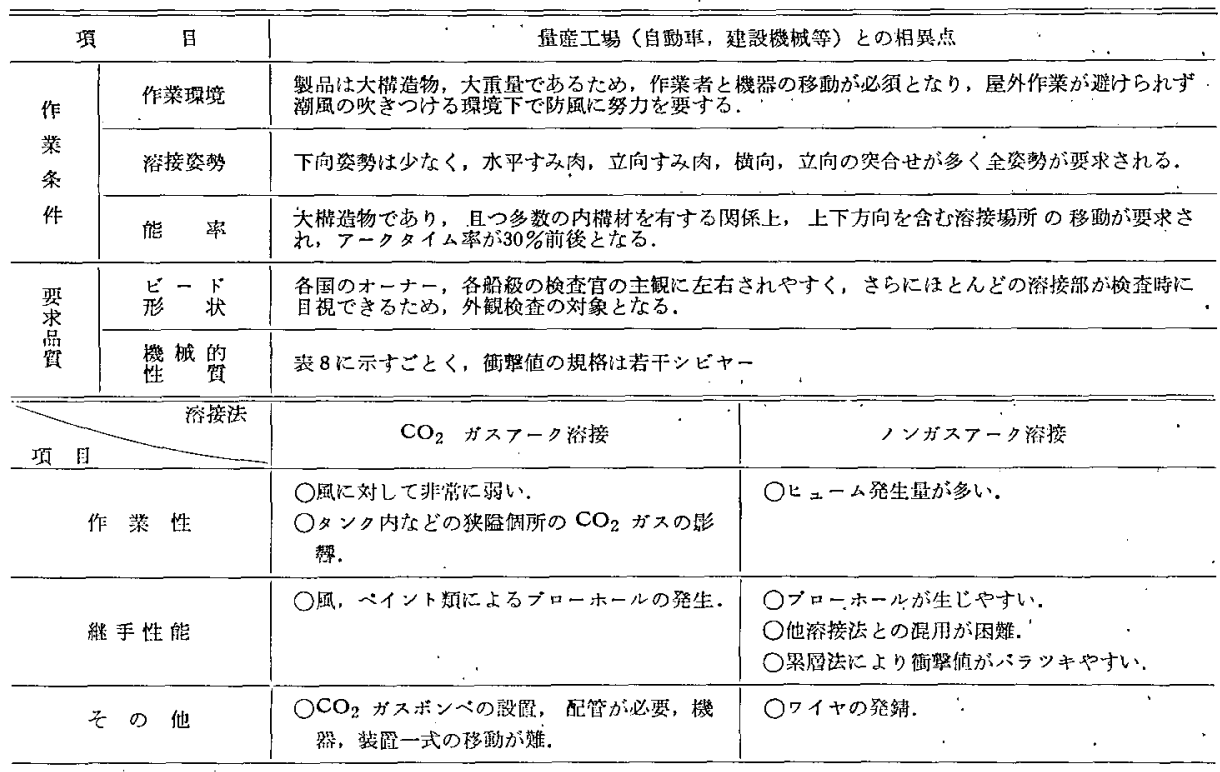

自動車，建設機械など甼産工場との甚本的な半自動溶 接採用上の相途点と， $\mathrm{CO}_{2}$ ガスアーク溶接とノンガス アーク溶接の造船における大きな問題点を表 9 にまとめ た. 他業種に較べて半自動溶接適用困難さが表より認め られよう。

$\mathrm{CO}_{2}$ ガスアーク溶接とノンガスアーク溶接の両者の うち、ノンガスアーク溶接の出現時には, 前者の採用 を大きく制約してきた，1）冷却水，シールドガスを必 要とするためト一千形状之重量の点で操作性が不良であ ること，2）風速 $2 \mathrm{~m} / \mathrm{sec}$ を超える作業環境におけるシ 一ルド不足によるブローホールの発生, の 2 点を解決し た方法とみなされ，さらに既存の手溶接用交流電源がそ のまま使用できる点も大い化あづかって，ノンガスアー ク溶接法の導入テストが多数の造船所において熱心に行 なわれたが，本溶接法の有する根本的な欠点，すなわ
ち，1）ヒュームの発生量が極めて多い，2）溶接条件簌 囲 (アーク䨮圧箱团) が狭い，3）手溶接, サブマージ アーク溶接との混用に難点がある。などの火点がはっき りするにしたがい，その適用個所は限定されたものとな ってきた。いっぽう $\mathrm{CO}_{2}$ ガスアーク溶接は導入初期 に較べて, 溶接機器と溶接ワイヤの改善が進み, 最近で は 500A 容量の機器でも冷却水が不娎のものが現われ， ワイヤフィーダの可般性とトーチの操作性も著しく改善 されており，直流電源の琎格の低下とあいまって，その 適用個所は着実に増加しつつある. 図 2 に示した $\mathrm{CO}_{2}$, ノンガスの溶接機所有台数よワイヤ使用㫫の伸びの変化 はその傾向を明らかにしている.しかし風によるシール ド不足のブローホールの問題は依然として $\mathrm{CO}_{2}$ ガスア 一ク溶接法の最大の弱点であり, ノズルの改良, ガス流 量の増加によるシールド能力の向上などの試みととあ 


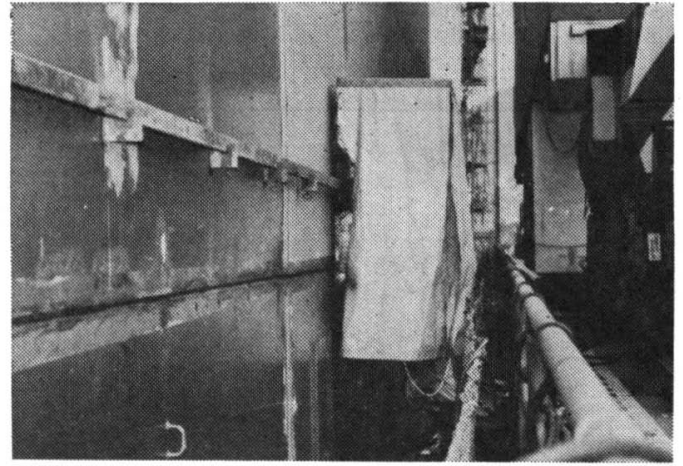

写真 5 カンバスに覆われた船側外板シームの $\mathrm{CO}_{2}$ ガス自動溶接装置

に，写真例にみられるごときカンバスで完全に覆う防風 対策や，ノズル先端部のアスベストの耐熱防風カバーの 使用などの工夫がなされているが, 継手品質の安定化の ためにはさらに機器, 材料の改良と現場の管理の努力が 要求されよう.

\section{4. 造船における半自動溶接の将来}

曲りプロックや船台工程でのプロック継手の片面溶接 が, 半自動溶接機の投入とともに増加して進行している が, そのほか半自動溶接の特長である簡便さをそのまま 生かし, 簡便な治具類, アタッチメントや台車などと組 合せて, 半自動溶接のより有効な使用法としての自動化 が進められるであろう. また設置溶接機台数の増加によ る移動距離の減少も可搬性の障害を著しく軽減するであ ろうし, 工場内でのガスの配管を実施して機器の移動性 を高めている造船所む既に現われており，作業ユニット の出現とともに将来は船台工程においてもガスの配管が ユニット単位で行なわれるようになろう.

しかしととで手溶接の $1.5 \sim 3$ 倍の能率向上となると いわれている半自動溶接の内蔵する根本的な問題点に目 を向けると, 半自動溶接の将来はけっして無条件に拡大 されてゆくとは言いがたい. 溶接作業は元来ある程度の 熟練度が要求されるものであり, さらに作業はアークの 強い光にさらされ, 非常な高温とフュームを伴うもので ある. 最近の若年新規就職者の傾向を見れば, 労働集約 型の典型である造船において溶接作業の省力化は切実な 問題となっている. 能率の面からみれば手溶接の1.5〜 3 倍の能率向上が期待できる半自動溶接も, この観点か ら見れば全く無力であり, 場合によっては手溶接作業よ りあ作業者への負担がふえる恐れああり, 手溶接からサ ブマージアーク溶接への転換があたらしたような極めて 大きな作業環境の改善は期待すべくむなく，との問題が
半自動溶接の適用拡大の 1 つの障害であったととは否定 できない.

船体の大型化と新鋭造船所の建設, 主力造船所ごとの グループ化により, 従来種々のタイプ, 大きさの船体が 建造されていたのが, 各造船所ごとに船型と大きさをほ ぼ専門化して建造する体制への移行につれて溶接作業の 省力化は，ますます重要な課題となってきている.

これらの現状に対して, 材料メーカーを中心として, 機器メーカーや造船所において省力化型の溶接材料, 新 溶接法の開発が進められてきたが, さらに最近では省力 化のための新しい溶接施工法とこの施工法と組合せた省 力装置の開発が盛んになりつつある.

表10は乙れらの新しい省力施工法のうちのいわゆる半 自動溶接として用いられていた $\mathrm{CO}_{2}$ ガスアーク溶接と ノンガスアーク溶接の省力化機器への発展例を示したも のであるが, これらは可視アークで全姿勢で溶接可能と いう特長を, さらに省力化機器としての適用を可能にす るため, 電源, 機械, 材料, 施工法などの総合的な研究 開発により生れたあのである.

立向すみ肉の省力化機器としては, 交流をサイリスタ による位相制御によって, 休止期間を有する波形にか え, アークを安定化させ, 電流あるいは電圧の変化を瞬 時に行なわせる新電源電源（ＳＰ）と，ウィービング機 構を組合せた方式と, さらにこの交流位相制御電流を約 1 秒単位の周期で強弱をつけることによりストレート運 棒上進を行なう方式 (SP-CC 法) の 2 種類があり, 両 者ともノンガス・ワイヤが用いられる.

立向突合せにおいては, ショートアーク溶接の厚板へ の適用が融合不良の問題で適用困難であったのが, ショ ートアークとスプレーアークを交番させる電源の開発に より可能とした方法 (SS-ARC 法) があり, また半自動 溶接のウィービングパターンの幑底した解析の上に完成

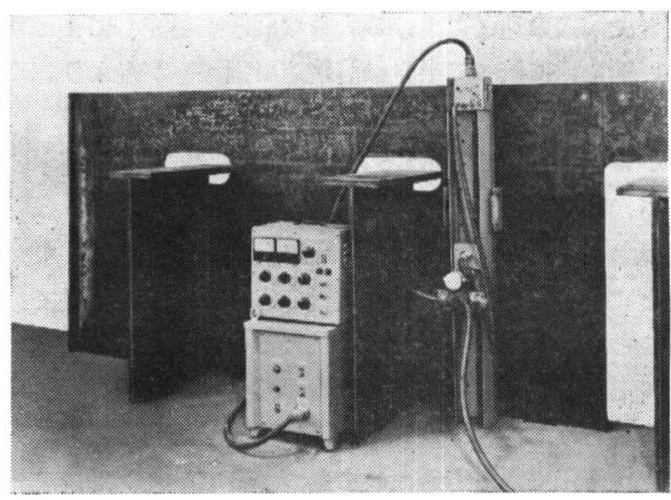

写真 6 ストレート上進立向すみ肉溶接装置 ( TC-1) 
表10 半自動溶接の省力化機器への発展例

\begin{tabular}{|c|c|c|c|c|c|}
\hline 勢 & \multicolumn{2}{|c|}{ 施工法名称 } & 溶 接法 & 特 & 適 用 個 所 \\
\hline \multirow{4}{*}{ 立向すみ肉 } & $\begin{array}{l}\text { ストレート } \\
\text { 上進 }\end{array}$ & $\begin{array}{c}\mathrm{SP}-\mathrm{CC} \\
\text { 法 }\end{array}$ & ノンガス & $\begin{array}{l}\text { 交流位相制御電流の強弱を周期的に繰返しストレート } \\
\text { 上進 1バスズ }\end{array}$ & \multirow{4}{*}{ 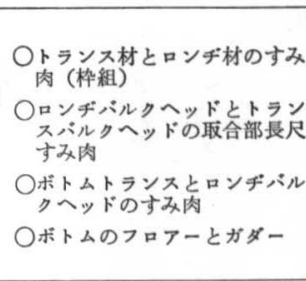 } \\
\hline & \multirow{3}{*}{$\mid \begin{array}{l}\text { ウイービンク } \\
\text { 上進 }\end{array}$} & SP 法 & ノンガス & 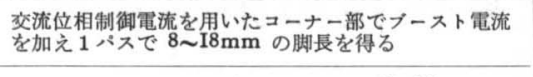 & \\
\hline & & $\underset{\mathrm{F} \text { 法 }}{\mathrm{O}}$ & $\begin{array}{c}\mathrm{CO}_{2} \\
(\text { ソンガス }\end{array}$ & シ最ートアークウイービングで 1 バス 8〜18 mm の & \\
\hline & & マグトレーサ & $\begin{array}{c}\mathrm{CO}_{2} \\
(\text { ソンガス })\end{array}$ & 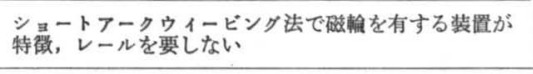 & \\
\hline \multirow{3}{*}{ 立向突合せ } & \multirow{3}{*}{$\begin{array}{l}\text { ウイービンク } \\
\text { 上進 }\end{array}$} & \begin{tabular}{|l|} 
デルタオッシ \\
レート法
\end{tabular} & $\mathrm{CO}_{2}-\mathrm{Ar}$ & 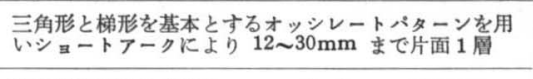 & \multirow{5}{*}{ 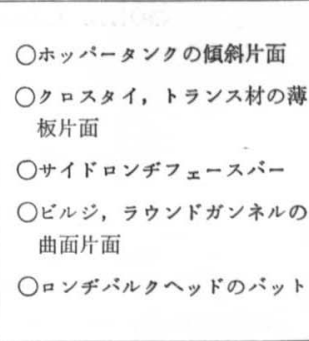 } \\
\hline & & $\begin{array}{l}\text { OSCON } \\
-\mathrm{VB} \text { 法 }\end{array}$ & $\mathrm{CO}_{2}$ & $\begin{array}{l}\text { 逆U形を基本とするオッシレートパターンによるショ } \\
\text { ーアーク面溶接 }\end{array}$ & \\
\hline & & $\underset{\text { 法 }}{\text { SS-ARC }}$ & $\mathrm{Ar}-\mathrm{CO}_{2}$ & 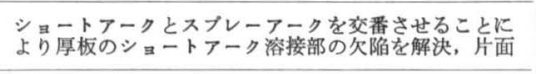 & \\
\hline \multirow{2}{*}{$\begin{array}{l}\text { 立向(上向) } \\
\text { 突合せ }\end{array}$} & \multirow{2}{*}{$\begin{array}{l}\text { ストレート } \\
\text { 上進 }\end{array}$} & RAN 法 & $\mathrm{Ar}-\mathrm{CO}_{2}$ & $\begin{array}{l}\text { 直流矩形波を用いフークの ON, OFF による開先ナ } \\
\text { ローギャッブ法, 欠陥なく勒性良好 }\end{array}$ & \\
\hline & & PAW 法 & $\mathrm{Ar}-\mathrm{CO}_{2}$ & 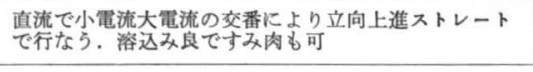 & \\
\hline \multirow{2}{*}{ 横向突合せ } & ストレート & M3 法 & $\begin{array}{l}\text { ソガス } \\
\left(\mathrm{CO}_{2}\right)\end{array}$ & $\begin{array}{l}\text { ストレート往復パターンを採用し，下向肉盛要筫で行 } \\
\text { ならっ短尺の板に適す }\end{array}$ & \multirow{2}{*}{$\begin{array}{l}\text { Oトランス材のフェースバー } \\
\text { Oサイドシェル,トランスバル } \\
\text { クヘッドのシーム }\end{array}$} \\
\hline & ウ1ービンク & M3Z 法 & $\begin{array}{l}\text { 次ガス } \\
\left(\mathrm{CO}_{2}\right)\end{array}$ & 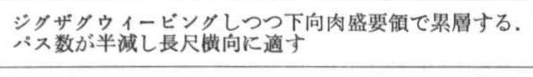 & \\
\hline \multirow{2}{*}{ 下向突合せ } & \multirow{2}{*}{ ウイービング } & 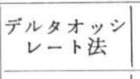 & $\begin{array}{c}\mathrm{CO}_{2} \\
\left(\mathrm{CO}_{2}-\mathrm{Ar}\right)\end{array}$ & 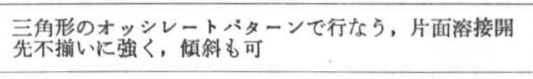 & \multirow{2}{*}{$\begin{array}{l}\text { ○曲り部の板継片面 } \\
\text { ○サイドロンヂウェブ } \\
\text { ○クロスタイのフェースパー } \\
\text { ○トランス材のフェースパー }\end{array}$} \\
\hline & & $\begin{array}{l}\text { OSCON } \\
-\mathrm{VF} \text { 法 }\end{array}$ & $\mathrm{CO}_{2}$ & $\begin{array}{l}\text { 単純ウ イービングで行なら, 片面溶接, 開先不渞いに } \\
\text { 强く, 佂も可 }\end{array}$ & \\
\hline
\end{tabular}

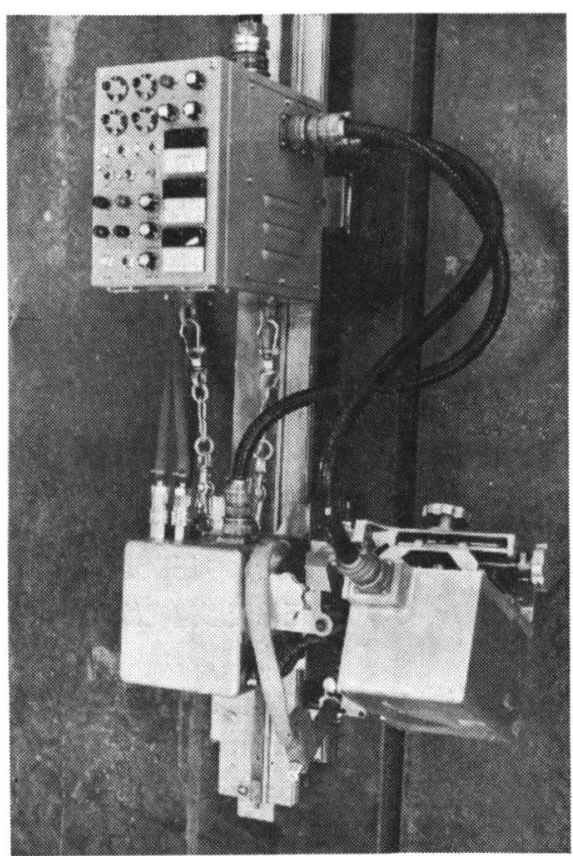

写真 7 デルタオッシレートによる立向突 合溶接装置 (DT-2)

した特殊なウィービングパターンを採用したショート アーク条件で行なう方法（デルタオッシレート法, OSCON-VB 法) がある. 立向突合せではシールドガス
あ $\mathrm{CO}_{2}$ ガスのみならず, $\mathrm{Ar}$ ガスとの組合せで用いら れる.

横向および下向の突合溶接においても, それぞれの適 用目的に合せたウィービンク法が工夫されている.

これらの省力化施工法の装置は, 実際の溶接アーク現 象を詳しく観察しつつ, 開発されて抢り, 単なるアーク の溶接線方向の移動のみであった従来の自動溶接機の概 念を越えて発達しつつある.

さらにての種の省力化機器は, 自動溶接では不可能で あった ONE MAN MULTI-ARC への道をひらくむ のであり, これらの省力化装置のシステム化された適用 は, 能率の向上, 工期の短縮之ともに継手品質の安定化 および作業環境の改善に大きく役立つであろう.

以上の観点にたてば, 造船における半自動溶接の将来 は, 半自動溶接材料, 機器の手溶接に準ずる操作性と安 定性の追求の努力はもちろん続けられようが, さらに半 自動溶接という枠を取払った， $\mathrm{CO}_{2}$ ガスアーク溶接 (ガ スシールドアーク溶接)，ノンガスアーク溶接をベース にした省力化施工法としての発展が今後ますます強まる であろシ。

\section{参考引用文献}

1）岡本, 厷㶆, 宮本, “造船に扰ける半自動溶接の使用現況”, 溶接 技術, Vol. 17, (1969) No. 3, 33

2）広瀬，宮本，“半自動溶接の造船への適用”，溶接技術，Vol. 19 (971), No. 1, 70

現場写真提供: 三菱重工業長崎造船所 